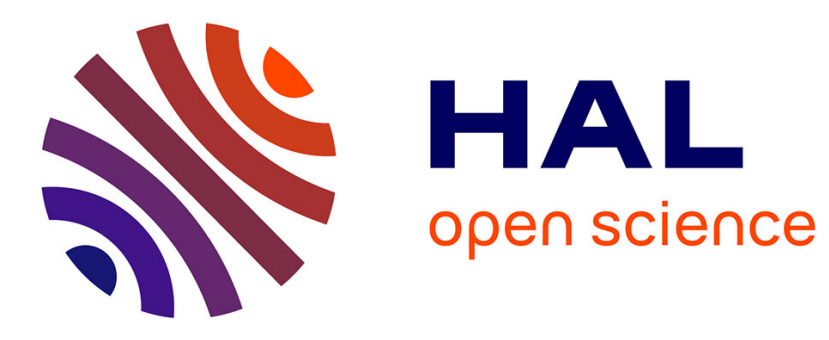

\title{
Spark Plasma Sintering and Hot Pressing of Hetero-Doped LaNbO4.
}

\author{
Guttorm E. Syvertsen, Claude Estournès, Harald Fjeld, Reidar Haugsrud, \\ Mari-Ann Einarsrud, Tor Grande
}

\section{- To cite this version:}

Guttorm E. Syvertsen, Claude Estournès, Harald Fjeld, Reidar Haugsrud, Mari-Ann Einarsrud, et al.. Spark Plasma Sintering and Hot Pressing of Hetero-Doped LaNbO4.. Journal of the American Ceramic Society, 2012, 95 (5), pp.1563-1571. 10.1111/j.1551-2916.2012.05101.x . hal-03468686

\section{HAL Id: hal-03468686 https://hal.science/hal-03468686}

Submitted on 7 Dec 2021

HAL is a multi-disciplinary open access archive for the deposit and dissemination of scientific research documents, whether they are published or not. The documents may come from teaching and research institutions in France or abroad, or from public or private research centers.
L'archive ouverte pluridisciplinaire HAL, est destinée au dépôt et à la diffusion de documents scientifiques de niveau recherche, publiés ou non, émanant des établissements d'enseignement et de recherche français ou étrangers, des laboratoires publics ou privés. 


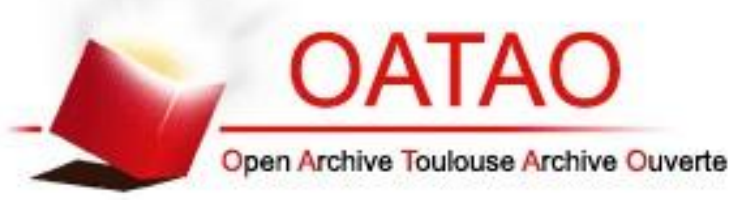

Open Archive Toulouse Archive Ouverte (OATAO)

OATAO is an open access repository that collects the work of Toulouse researchers and makes it freely available over the web where possible.

This is an author-deposited version published in:_http://oatao.univ-toulouse.fr/ Eprints ID: 8706

Official URL: http://dx.doi.org/10.1111/j.1551-2916.2012.05101.x

\section{To cite this version:}

Syvertsen, Guttorm E. and Estournès, Claude and Fjeld, Harald and Haugsrud, Reidar and Einarsrud, Mari-Ann and Grande, Tor Spark Plasma Sintering and Hot Pressing of Hetero-Doped LaNbO4. (2012) Journal of the American Ceramic Society, vol. 95 ( ${ }^{\circ}$ 5). pp. 1563-1571. ISSN 0002-7820

Any correspondence concerning this service should be sent to the repository administrator: staff-oatao@inp-toulouse.fr 


\title{
Spark Plasma Sintering and Hot Pressing of Hetero-Doped LaNbO
}

\author{
Guttorm E. Syvertsen, ${ }^{\ddagger}$ Claude Estournès, ${ }^{\S}$ Harald Fjeld, ${ }^{\natural}$ Reidar Haugsrud, \\ Mari-Ann Einarsrud, and Tor Grande \\ ${ }^{\ddagger}$ Department of Materials Science and Engineering, Norwegian University of Science and Technology, \\ NO-7491 Trondheim, Norway \\ ${ }^{\S}$ CIRIMAT et Plateforme National de Frittage Flash du CNRS (PNF2-MHT-UPS), Université Paul-Sabatier, \\ 118 Route de Narbonne, 31062 Toulouse, France \\ ${ }^{\ddagger}$ FERMiO, Department of Chemistry, University of Oslo, Gaustadalléen 21, NO-0349 Oslo, Norway
}

\begin{abstract}
$\mathrm{LaNbO}_{4} / \mathrm{La}_{3} \mathrm{NbO}_{7}$ and $\mathrm{LaNbO}_{4} / \mathrm{LaNb}_{3} \mathrm{O}_{9}$ cer-cer composites were prepared by impregnating Ca-doped $\mathrm{LaNbO}_{4}$ powder, synthesized by spray pyrolysis, with La- or Nb-precursor solutions. The sintering of the calcined powders was investigated by dilatometry, and dense composites were prepared by conventional sintering, hot pressing, and spark plasma sintering. The particle size of the starting powders was about $50 \mathrm{~nm}$, and the average grain size of the dense materials ranged from $100 \mathrm{~nm}$ and upwards, depending on the sintering temperature, sintering procedure, and the phase composition. The unit cell parameters of $\mathrm{LaNbO}_{4}$ showed a finite size effect and approached the cell parameters of tetragonal $\mathrm{LaNbO}_{4}$ with decreasing crystallite size, both for the single-phase material and the composites. The minority phase $\left(\mathrm{La}_{3} \mathrm{NbO}_{7}\right.$ or $\left.\mathrm{LaNb}_{3} \mathrm{O}_{9}\right)$ were observed as isolated grains and accumulated at triple points and not along the grain boundaries, pointing to a large dihedral angle between the phases. The calcium-solubility in the minority phases was larger than in $\mathrm{LaNbO}_{4}$, which corresponds well with previous reports. The electrical conductivity of the heterodoped materials was similar to, or lower than, that for Ca-doped $\mathrm{LaNbO}_{4}$.
\end{abstract}

\section{Introduction}

A relatively high proton conductivity in rare-earth orthoniobates and -tantalates was reported by Haugsrud and Norby some years ago. ${ }^{1}$ The highest proton conductivity was found for $\mathrm{CaO}$ or $\mathrm{SrO}$-doped $\mathrm{LaNbO}_{4}$, and this material has been suggested as an alternative electrolyte in proton conducting solid oxide fuel cells (SOFCs) due to its high stability in $\mathrm{CO}_{2}-$ and $\mathrm{H}_{2} \mathrm{O}$-containing atmospheres compared with conventional proton conducting electrolyte materials. ${ }^{1,2}$ $\mathrm{LaNbO}_{4}$ has a monoclinic structure (space group $C 2 / c$ ) at room temperature, and undergoes a second order phase transition around $520^{\circ} \mathrm{C}$ to a tetragonal phase (space group $I 4_{1} / a$ ), where the low-temperature monoclinic polymorph of $\mathrm{LaNbO}_{4}$ is ferroelastic. ${ }^{3,4}$

Proton migration in $\mathrm{LaNbO}_{4}$ occurs by hopping from oxygen ion to oxygen ion, as described in general by e.g., Kreuer. ${ }^{5}$ Substitution of less than $1 \mathrm{~mol} \%$ of calcium for lanthanum increases the proton conductivity by more than one order of magnitude as a consequence of increasing the number of oxygen vacancies, which will increase the proton

M. Menon-contributing editor concentration when hydrated under wet conditions. ${ }^{2,6,7}$ The alkaline earth oxide solubility limit in $\mathrm{LaNbO}_{4}$ has been previously reported to be below $1 \mathrm{~mol} \%{ }^{7}$ and further increase in the acceptor concentration will lead to formation of secondary phases without increasing the bulk conductivity as shown recently. ${ }^{8}$

The proton conductivity of $\mathrm{LaNbO}_{4}$-based materials is still considerably lower than for materials currently used in SOFC, which calls for alternative avenues for improving the proton conductivity. ${ }^{9,10}$ One approach is to incorporate a minority phase in the electrolyte, referred to as hetero-doping, in means of two coexisting phases in the material. ${ }^{11,12}$ In single-phase, or homophase, materials the defects are homogeneously distributed throughout the bulk with defect profiles present at the grain boundaries due to space charges. For hetero-doped materials, the defect profiles through the interfaces between the two phases will differ from singlephase materials as there is a chemical potential difference between the two phases. ${ }^{13}$ The minority phase could be located along the grain boundaries, at triple points between grains, or as sub-grains within the grains of the majority phase. Fig. 1 illustrates the two extreme cases of the microstructure, together with the interfaces one will encounter. Percolation of the minority phase may occur, depending on interfacial energies (dihedral angle), the grain size, and the volume fraction of the two phases. ${ }^{14}$ If the volume fraction of the minority phase is low, percolation will not occur, and only a minor effect on the total conductivity can be observed due to the isolated grains. On the other hand, if the volume fraction is large, and the minority phase has lower conductivity than the majority phase, the conductivity will be suppressed as the grains perpendicular to the current direction block the charge carriers. ${ }^{15}$ When the interfacial energy for the heterophase interface relative to the homophase interface is low (small dihedral angle), the minority phase will be located at the grain boundaries of the majority phase, see Fig. 1(A), and one encounters percolating heterophase interfaces when the volume fraction of the minority phase is sufficiently high. As the space charge potential is different at this interface, compared with the homophase interface, the defect concentrations in these space charge zones will change. This could therefore alter the transport processes along the phase boundary zone in Figs. 1(D)-(E), thus creating a highly conducting path for the charge carriers depending on the sign and magnitude of the space charge potential. A small grain size will enhance this effect as the grain boundaries and space charge layer thickness will be larger relative to the bulk volume, and materials with sub-100 nm grains often show finite size effects. ${ }^{15-19}$ If the dihedral angle is large (large interfacial energy), the minority phase (AO) will, on the contrary, be located at triple points of the majority phase $\left(\mathrm{LaNbO}_{4}\right)$ as shown in Fig. 1(B). Then there will be three types of inter- 
(A)

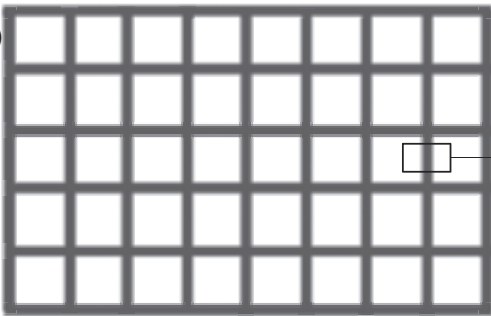

(C)

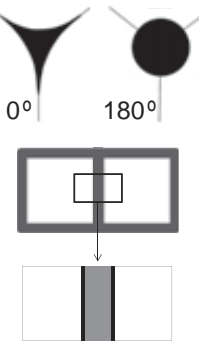

(B)
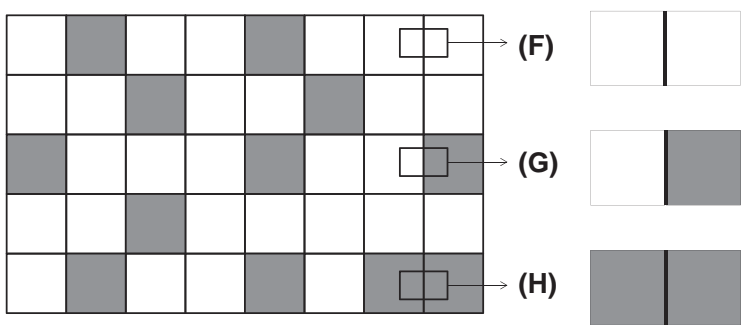

Fig. 1. Conceptual illustration of the microstructure of a composite material with $30 \mathrm{vol} \%$ minority phase when the dihedral angle between the phases is small (A) and large (B). Minority phase located at a triple point when the dihedral angle is $0^{\circ}$ and $180^{\circ}$, respectively $(\mathrm{C})$. Minority phase located at the phase boundary of the majority phase when dihedral angle is small (D) and (E). Homogeneous interface of majority phase (F), heterogeneous interface between majority and minority phase (G), and homogeneous interface of minority phase for large dihedral angle (H).

faces: $\mathrm{LaNbO}_{4}\left|\mathrm{LaNbO}_{4}, \mathrm{LaNbO}_{4}\right| \mathrm{AO}$, and $\mathrm{AO} \mid \mathrm{AO}$ as illustrated in Figs. 1(F)- $(\mathrm{H})$. In this case, to determine experimentally the transport properties of these interfaces independently will be very demanding. ${ }^{20}$

Spark plasma sintering reduces the sintering time and temperature compared with conventional sintering (CS), by applying high uniaxial pressure, while current pulses through the material. The shorter holding time and lower temperature reduce the grain growth significantly, simultaneously as composite microstructures not obtainable by CS can be fabricated. ${ }^{21,22} \mathrm{LaNb}_{3} \mathrm{O}_{9}$ and $\mathrm{La}_{3} \mathrm{NbO}_{7}$ are thermodynamically stable with $\mathrm{LaNbO}_{4}$ and were chosen as the minority phases in hetero-doped $\mathrm{LaNbO}_{4} \cdot \mathrm{La}_{2} \mathrm{O}_{3}$ and $\mathrm{Nb}_{2} \mathrm{O}_{5}$ can be considered as basic and acidic oxides, respectively, hence $\mathrm{LaNb}_{3} \mathrm{O}_{9}$ is more acidic and $\mathrm{La}_{3} \mathrm{NbO}_{7}$ more basic relative to $\mathrm{LaNbO}_{4}$. This will influence the chemical potential gradient across the heterophase interfaces. ${ }^{23}$ In this work, the sintering behavior, microstructure, and electrical properties of these composite materials are investigated to elucidate the possibility of developing hetero-doped $\mathrm{LaNbO}_{4}$.

\section{Experimental}

\section{(1) Material Preparation}

$\mathrm{La}_{0.995} \mathrm{Ca}_{0.005} \mathrm{NbO}_{4-\delta}(\mathrm{LN})$ powder was synthesized by spray pyrolysis (CerPoTech, Trondheim, Norway) from waterbased solutions of La-EDTA-complex, Nb-malic acid complex, and $\mathrm{Ca}\left(\mathrm{NO}_{3}\right)_{2}$. The solutions were made from $\mathrm{La}$ $\left(\mathrm{NO}_{3}\right)_{3}(99 \%$, Metal Rare Earth Limited, Shenzhen, China), ethylenediaminetatraacetic acid ( $\mathrm{H}_{4} \cdot$ EDTA) (99\% Sigma-
Aldrich, St. Louis, MO), ammonium niobium dioxalate oxide pentahydrate (H.C. Stark), DL-malic acid (99\%, SigmaAldrich Chemie, Goslar, Germany), and dried $\mathrm{Ca}\left(\mathrm{NO}_{3}\right)_{2}$ (99\%, Merck, Darmstadt, Germany) as described elsewhere. ${ }^{24}$ To prevent precipitation, the $\mathrm{pH}$ was adjusted with ammonium hydroxide $\mathrm{NH}_{4} \mathrm{OH}(25 \%)$ and $\mathrm{HNO}_{3}(65 \%)$ (both Merck). The concentration of the cations in the three solutions was determined by thermogravimetry prior to mixing to ensure the cation stoichiometry. Four composites, LN +10 or $30 \mathrm{vol} \% \mathrm{LaNb}_{3} \mathrm{O}_{9}(\mathrm{Nb} 10$ and $\mathrm{Nb} 30)$ and $\mathrm{LN}+10$ or $30 \mathrm{vol} \% \mathrm{La}_{3} \mathrm{NbO}_{7}$ (La10 and La30), were obtained by impregnating the as-prepared $\mathrm{LN}$ powder with excess La-EDTA- or Nb-malic acid solutions by stirring at $50^{\circ} \mathrm{C}$ until the water had evaporated. All powders were calcined at $650^{\circ} \mathrm{C}$ for $8 \mathrm{~h}$ and milled for $24 \mathrm{~h}$ using yttria-stabilized zirconia media grinding in $100 \%$ ethanol. The powders were further heated to remove organic residues in air at $400^{\circ} \mathrm{C}$ for $3 \mathrm{~h}$ followed by sieving through $250 \mu \mathrm{m}$.

The as-prepared $\mathrm{La}_{0.995} \mathrm{Ca}_{0.005} \mathrm{NbO}_{4-\delta}$ was sintered by using three different routes: CS, hot pressing (HP), and spark plasma sintering (SPS) and the sintering parameters are listed in Table I. Conventional sintering of LN pellets was performed in a muffle furnace in air. In case of HP, the LNpowder was sintered in carbon dies, using $\mathrm{BN}$ as lubricant, in argon and the temperature measured by pyrometer (HP50 7010G, Thermal Technology, Santa Rosa, CA). Circular disks of LN, Nb10, Nb30, La10, and La30 were made with SPS using a Dr. Sinter 2080 machine (Sumomito Coal Mining, Kawasaki, Japan) and carbon dies covered by graphite paper (ON/OFF: 12/2, $3.3 \mathrm{~ms}$ ). During SPS, the temperature was monitored by thermocouple (up to $\sim 1000^{\circ} \mathrm{C}$ ) or pyrometer (above $\sim 1000^{\circ} \mathrm{C}$ ).

\section{(2) Characterization}

Particle size of the obtained powders was calculated assuming spherical particles using specific surface areas measured by nitrogen absorption (BET, Tristar ${ }^{\mathrm{TM}}$ 3000, Micrometrics, Norcross, GA) . Particle size distribution of the powders was narrow as shown previously. ${ }^{24}$ Sintering was studied by dilatometry using a $5 \mathrm{~mm} \varnothing$ pellet in flowing synthetic air at $2{ }^{\circ} \mathrm{C} / \mathrm{min}$ (DIL 402C, Netzsch, Selb, Germany). Powder $\mathrm{X}$-ray diffraction (XRD) reflections were recorded from 20 to $80^{\circ}$ with step length of $0.01^{\circ}$ and counting time $0.4 \mathrm{~s}$ using a Bruker D8 Focus diffractometer (Bruker AXS, Karlsruhe, Germany) equipped with a Lynxeye ${ }^{\mathrm{TM}}$ (Bruker AXS) detector using $\mathrm{CuK \alpha}$ radiation. Crystallographic densities, unit cell parameters, and crystallite size were obtained from XRD patterns by Rietveld refinements (Topas v2.1, Bruker AXS). Atomic positions were not refined, and previously reported structural data were used. ${ }^{4,25,26}$ A Pearson type VII profile was used to describe the Bragg reflections, and the background was fitted using a Chebychev polynomial. The XRD of the SPS samples was performed on the polished disk surface to maintain the disks for subsequent electrical conductivity measurements. Relative densities were determined by Archimedes method using 2-propanol (ISO-5017). The samples were polished with diamond suspension, thermally etched $25^{\circ} \mathrm{C}$ below the sintering temperature for $0.1 \mathrm{~h}$ and examined in FEG-SEM (Supra 55VP, Carl Zeiss NTS, Oberkochen, Germany). Grain size was obtained by averaging between 150 and 500 grain intercepts of the electron micro-

Table I. Geometry and Sintering Parameters Used in the Different Sintering Routes: Conventional Sintering (CS), Hot Pressing (HP), and Spark Plasma Sintering (SPS)

\begin{tabular}{lllcrrr}
\hline $\begin{array}{l}\text { Sintering } \\
\text { method }\end{array}$ & $\begin{array}{c}\text { Diameter } \\
(\mathrm{mm})\end{array}$ & $\begin{array}{c}\text { Thickness } \\
(\mathrm{mm})\end{array}$ & $\begin{array}{c}\text { Temperature } \\
\text { range }\left({ }^{\circ} \mathrm{C}\right)\end{array}$ & $\begin{array}{c}\text { Heating rate } \\
\left({ }^{\circ} \mathrm{C} / \mathrm{min}\right)\end{array}$ & $\begin{array}{c}\text { Dwell time } \\
(\mathrm{min})\end{array}$ & $\begin{array}{c}\text { Applied } \\
\text { pressure }(\mathrm{MPa})\end{array}$ \\
\hline CS & 15 & 4 & $1050-1250$ & 3.33 & 480 & None \\
HP & 25 & 2 & $900-1050$ & 10 & 60 \\
SPS & 20 & 2 & $800-1150$ & $100-250$ & $0-5$ & $100-120$ \\
\hline
\end{tabular}


graphs. Grain boundaries and grain phase composition were investigated by transmission electron microscopy (TEM) (JEM-2010, JEOL, Tokyo, Japan) equipped with energy-dispersive X-ray spectroscopy (EDS).

The electrical properties of the materials were investigated in a measurement cell (Probostat ${ }^{\mathrm{TM}}$, NorECs, Oslo, Norway) where electrodes $(\sim 10 \mathrm{~mm} \varnothing, \mathrm{Pt}$-ink and Pt-net, Pt A3788A, Metalor, Birmingham, UK) were painted onto the disk surfaces. The total conductivity was measured as a function of $p_{\mathrm{O} 2}$ and $p_{\mathrm{H} 2 \mathrm{O}}$ (Model 1260A, Solartron Analytical, Farnborough, Hampshire, UK) at constant frequency of $10 \mathrm{kHz}$ and oscillating voltage of $0.5-1.0 \mathrm{~V}$. To obtain the bulk and interface resistances, impedance spectroscopy was performed on materials prepared by SPS under wet, reducing conditions $\left(5 \% \mathrm{H}_{2} / \mathrm{N}_{2}, 2.5 \% \mathrm{H}_{2} \mathrm{O}\right)$ in the frequency range $10^{-1}$ $10^{6} \mathrm{~Hz}$ and temperature range $900-300^{\circ} \mathrm{C}$. The impedance sweeps of LN, La10, La30, and Nb10 were fitted by ZView (v2.9, Scribner Associates, Southern Pines, NC), applying the equivalent circuits $\left(R_{1} Q_{1}\right)\left(R_{2} Q_{2}\right)$ below $400^{\circ} \mathrm{C}$ and $R_{1}\left(R_{2} Q_{2}\right)\left(R_{3} Q_{3}\right)$ above $425^{\circ} \mathrm{C}$, where $R_{i}$ and $Q_{i}$ denote resistance and constant phase element, respectively. $R_{1}$ and $Q_{1}$ are related to the bulk of the materials, while $R_{2}$ and $Q_{2}$ are allocated to the phase boundaries. Contributions at low frequencies $\left(R_{3}\right.$ and $\left.Q_{3}\right)$, which were assigned to electrode related processes, could not be fitted for all materials at the lowest temperatures. A stray capacitance of $5 \mathrm{pF}$ originating from the measurement setup was added in parallel to the other elements. Implementation of another $(R Q)$ element in the equivalent circuit model did not improve the fitting, which could have been expected due to the presence of two phases and the variation of interfaces. The interfacial resistivity reported is thus the contribution from the second arc-only corrected for the geometry of the samples-and is therefore dependent on the grain size. Phase boundary width, $g$, was estimated using the formula

$$
g=\left(C_{1} / C_{2}\right) G
$$

where $C_{1}$ and $C_{2}$ are the capacitances of the bulk and phase boundary from impedance spectroscopy, and $G$ is the average grain size of the material. ${ }^{27}$

\section{Results}

The powders were calcined at $650^{\circ} \mathrm{C}$ to conserve the small particle size of the powders, which was $47 \pm 5 \mathrm{~nm}$ estimated from the measured surface area. This particle size was about half of the particle size for powders calcined at $800^{\circ} \mathrm{C} .{ }^{24} \mathrm{X}$ ray diffraction of the conventionally sintered materials, see Fig. 2, confirmed the coexistence of $\mathrm{LaNbO}_{4}$ with either $\mathrm{LaNb}_{3} \mathrm{O}_{9}$ or $\mathrm{La}_{3} \mathrm{NbO}_{7}$. The phase content of the minority phase found by Rietveld refinement were $29 \mathrm{vol} \%$ (La30) and $27 \mathrm{vol} \%$ (Nb30) in good accordance with the nominal composition ( $30 \mathrm{vol} \%$ ). The corresponding values for the nominal $10 \mathrm{vol} \%$ materials were $9 \mathrm{vol} \%$ (La10) and $10 \mathrm{vol} \%$ (Nb10). The refined unit cell parameters for the $\mathrm{LaNbO}_{4}$ as well as $\mathrm{La}_{3} \mathrm{NbO}_{7}$ and $\mathrm{LaNb}_{3} \mathrm{O}_{9}$ (not shown here) were in agreement with literature data. ${ }^{4,25,26}$

The sintering of the various powders studied by dilatometry is shown in Fig. 3. The densification starts at lower temperatures for $\mathrm{Nb} 10$ and $\mathrm{Nb} 30$ relative to $\mathrm{LN}$, resulting in a lower sintering temperature to achieve complete densification. A large increase in the onset of densification was observed for La10 and La30 compared with LN. The small contraction at $\sim 700^{\circ} \mathrm{C}$ is caused by decomposition of organic residuals, which were not removed during calcination at $650^{\circ} \mathrm{C}$. A similar contraction was also observed by SPS. The ferroelastic transition temperature observed during cooling was around $520 \pm 10^{\circ} \mathrm{C}$ for all the compositions (insert Fig. 3).

The sintered materials were black after HP or gray with black spots after SPS. After thermal annealing in air, the materials became white. The black appearance is probably

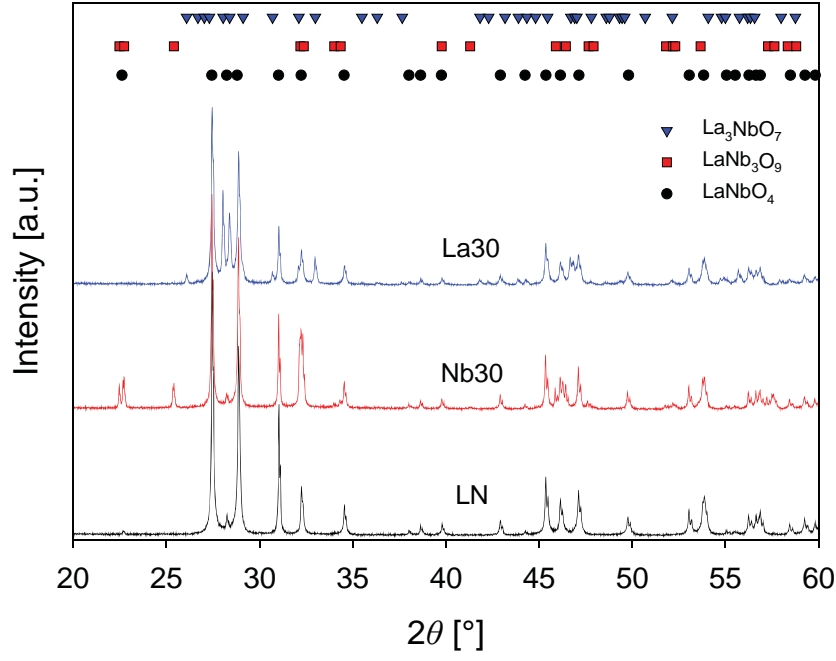

Fig. 2. X-ray diffractograms of LN, La30, and Nb30 conventionally sintered at $1300^{\circ} \mathrm{C}$ for $8 \mathrm{~h}$. Top: reported reflections for the three phases. ${ }^{4,25,26}$

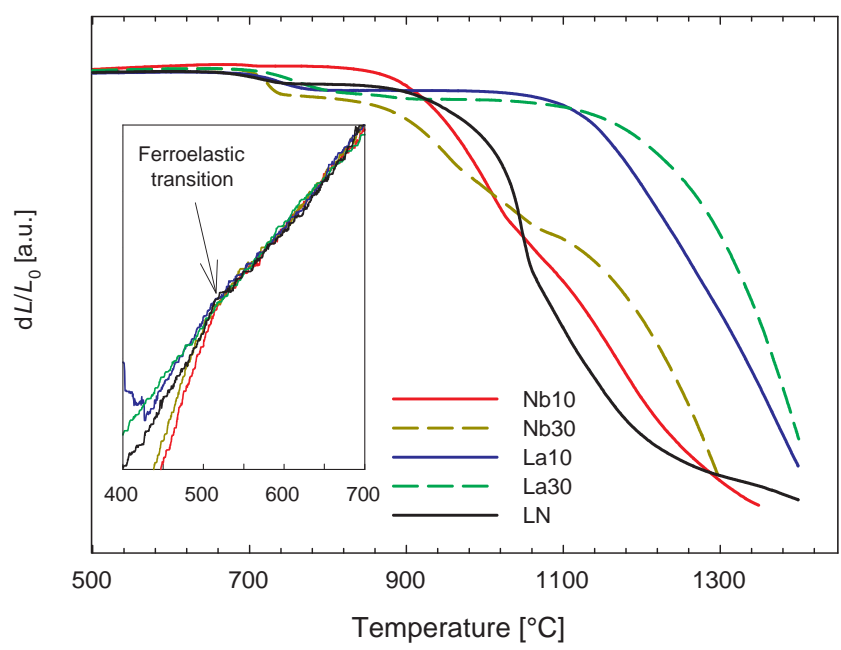

Fig. 3. Dilatometer curves of LN, Nb10, Nb30, La10, and La30 during $2^{\circ} \mathrm{C} / \mathrm{min}$ in air. The insert shows the cooling curve around the phase transition temperature of $\mathrm{LaNbO}_{4}$.

caused by partial reduction of niobium or traces of contaminations because of the reducing conditions during HP/SPS in carbon dies. The samples appeared white after CS in air.

The relative densities of the materials prepared by the different sintering routes are displayed in Fig. 4(A). The relative density followed approximately the same trend with temperature for all the three sintering methods, but was shifted relative to each other. LN sintered at the lowest temperature by SPS, followed by HP and CS. LN did reach $\sim 96 \%$ of relative density by SPS, although a few of the SPS samples achieved a higher density at lower temperatures. The larger grain size in these samples see Fig. 4(B), suggests that the effective temperature was higher than the set-up temperature, which could result from joule heating due to the pulsed current through the sample. The sintering temperature was reduced by $\sim 150^{\circ} \mathrm{C}$ going from CS to SPS or HP. This is in agreement with expectations as the applied pressure (Table I) would enhance the densification rate. $\mathrm{Nb} 30$ and Nb10 sintered at a lower temperature compared with LN using SPS, while La30 and La10 both required a higher sintering temperature. All the composites sintered rapidly within a narrow temperature range, and close to full relative density was achieved by SPS at $850-900^{\circ} \mathrm{C}$ for the $\mathrm{Nb}_{2} \mathrm{O}_{5}$-rich composites and at 1050 $1100^{\circ} \mathrm{C}$ for the $\mathrm{La}_{2} \mathrm{O}_{3}$-rich composites.

The grain size of the various materials is shown in Fig. 4(B). Grain size is here defined as the average size of the 


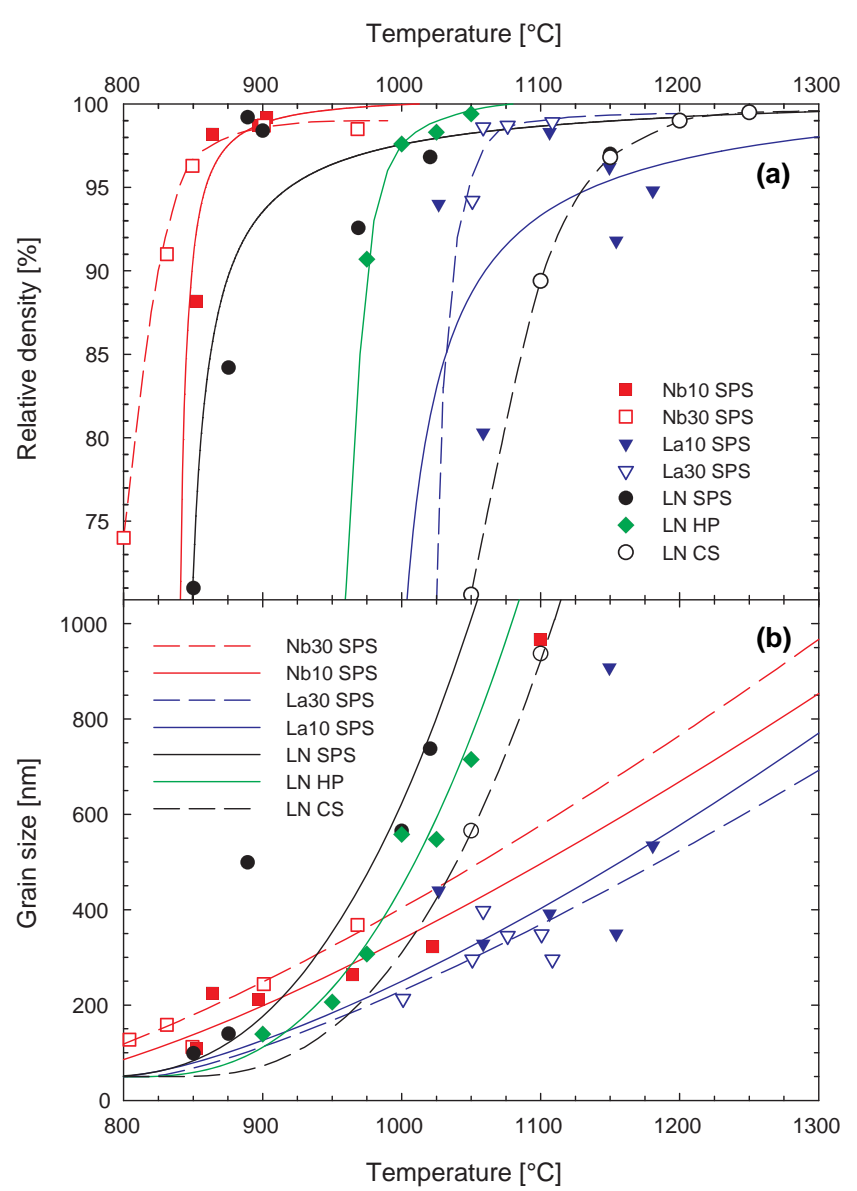

Fig. 4. Relative density (A) of LN [hot pressing (HP), conventional sintering (CS), and spark plasma sintering (SPS)], Nb10, Nb30, La10, and La30 (only SPS), and average grain size (B) as function of maximum sintering temperature. Note that the loading program and the sintering times and applied loads varied for the spark plasma sintered samples. Lines are guides to the eye.

individual grains. The grain size of the LN materials increased exponentially with temperature with the smallest grains achieved by SPS, followed by HP and CS. The grain growth in the composites is considerably lower and the grains grew linearly with respect to temperature, implying that the minority phases hinder grain growth of LN at elevated temperatures. Grain coarsening was observed to occur prior to complete densification, which hindered the preparation of dense composites of sub-100 nm grains as shown in Fig. 5. By comparing the relationship between the grain size and the relative density obtained by the three sintering methods, HP and SPS were superior to CS. HP did in general produce smaller grains than SPS at the same density.

The ferroelastic nature of monoclinic $\mathrm{LaNbO}_{4}{ }^{28}$ gives rise to peak broadening due to ferroelastic domains, which makes it difficult to obtain the grain size by XRD. The crystallite size or ferroelastic domain size of LN proved to be independent of the phase composition; however, it was dependent on the grain size of LN (Fig. 6), and hence it can be used to compare the grain size of the different materials. It has previously been suggested that the domain geometry is dependent on the grain size, ${ }^{29}$ in accordance with the present data. The unit cell parameters possessed a finite size effect as evident in Fig. 7, demonstrating that the deviation from bulk LN becomes more pronounced with decreasing domain (and grain) size. The lattice parameters for the materials with the three largest crystallite sizes (obtained by CS) were in good agreement with lattice parameters for bulk LN. ${ }^{4}$

The coexistence of the two phases in the composites is demonstrated in Fig. 8, where the grain size of the compos-

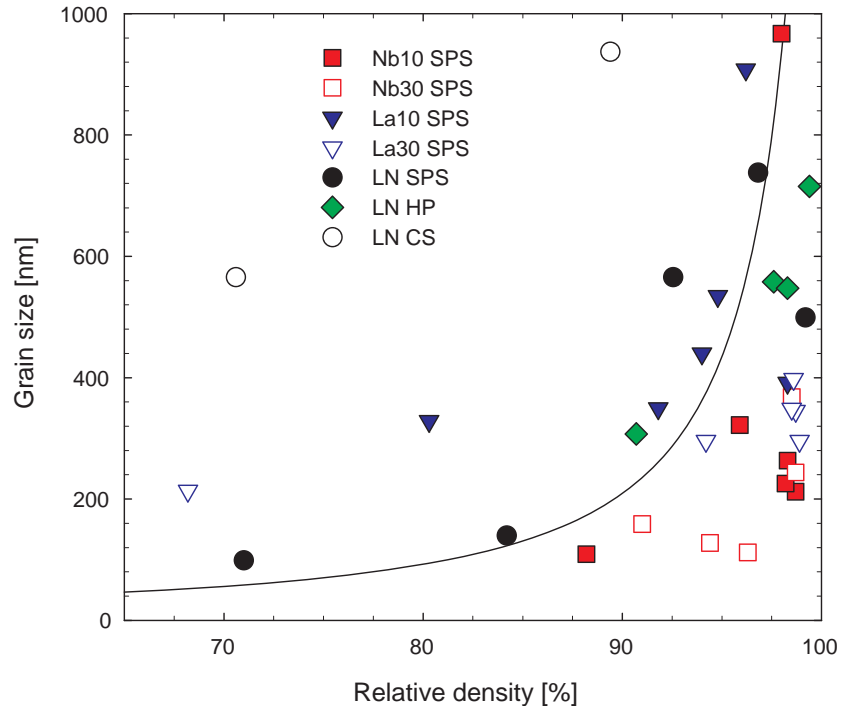

Fig. 5. Relative density of the $\mathrm{LN}, \mathrm{Nb} 10, \mathrm{Nb} 30$, La10, and $\mathrm{Nb} 30$ materials compared with the grain size. Line represents a guide to the eye to highlight the grain growth as the materials reached higher densities.

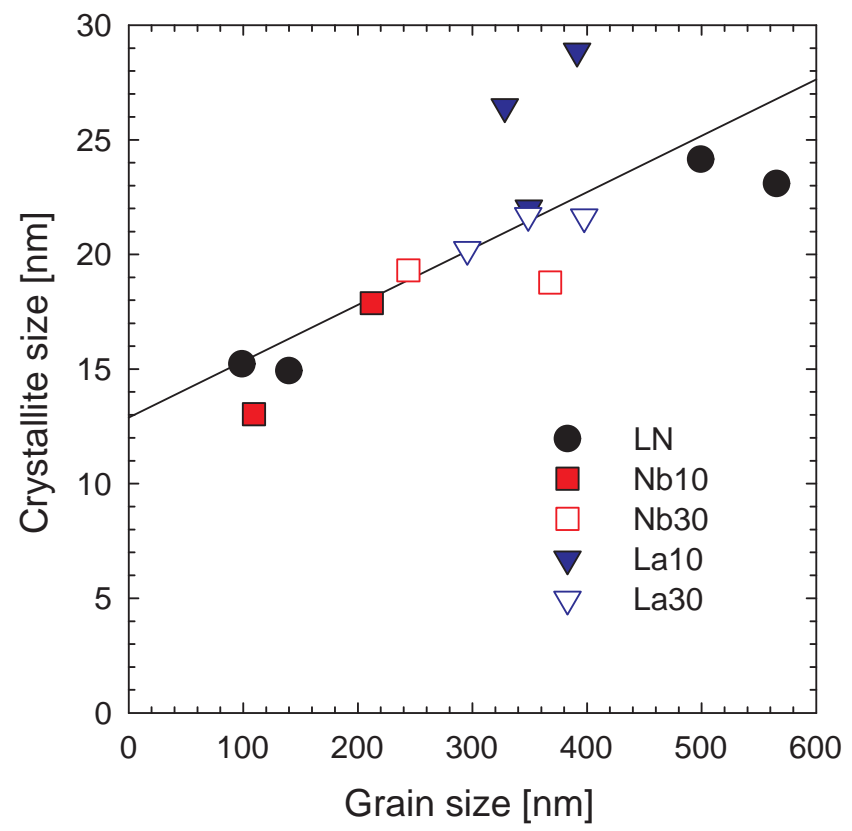

Fig. 6. Crystallite size versus grain size for LN, Nb10, Nb30, La10, and La30 SPS materials. The line is a guide to the eye.

ites $\mathrm{Nb30}$ and La30 can be compared with the single-phase LN material. Ferroelectric domains of $\mathrm{LaNbO}_{4}$ in $\mathrm{La} 10$ are evident in the transmission electron micrographs shown in Fig. 9(A). The composition of the minority phases $\mathrm{La}_{3} \mathrm{NbO}_{7}$ and $\mathrm{LaNb}_{3} \mathrm{O}_{9}$ in the composites $\mathrm{La} 10$ and $\mathrm{Nb} 10$, respectively, was confirmed by EDS, and the composite microstructure is shown in the micrograph of La10, see Fig. 9(B). No accumulation of one specific metal oxide (binary or ternary) could be found at the homophase $\mathrm{LaNbO}_{4}$ grain boundaries investigated by high-resolution TEM/EDS. Calcium was not detected (within error margins) in any of the $\mathrm{LaNbO}_{4}$-grains, suggesting that calcium is more soluble in the minority phases. The EDS analysis confirmed the presence of $\mathrm{Ca}$ in the minority phases and the presence of minor impurities of silicon oxide, accumulated at some triple points as reported previously. ${ }^{6}$

The bulk conductivity of the materials LN, Nb10, La10, and La30 under wet, reducing conditions $\left(5 \% \mathrm{H}_{2} / \mathrm{Ar}, 2.5 \%\right.$ 


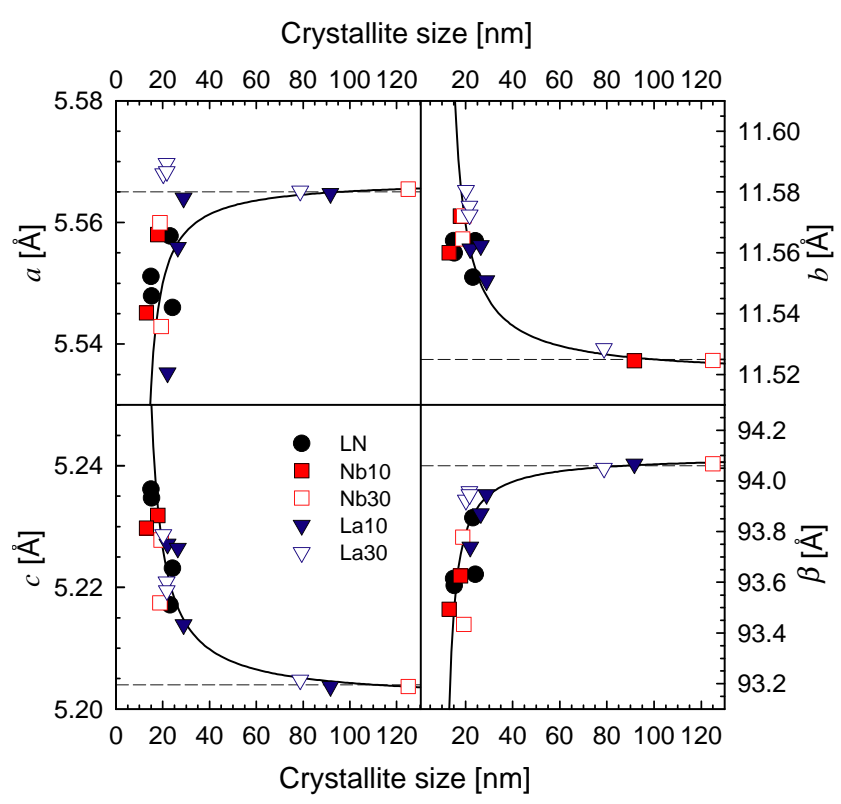

Fig. 7. Cell parameters $a, b, c$, and $\beta$ of the $\mathrm{La}_{0.995} \mathrm{Ca}_{0.005} \mathrm{NbO}_{4-\delta^{-}}$ phase plotted against calculated crystallite size for $\mathrm{LN}, \mathrm{Nb} 10, \mathrm{Nb} 30$, La10, and La30 materials. Bulk values are represented with dotted lines $\left(a=5.565 \AA, b=11.525 \AA, c=5.204 \AA\right.$, and $\left.\beta=94.06^{\circ}\right)$ and solid lines are guides to the eye.

$\mathrm{H}_{2} \mathrm{O}$ ) is displayed in Fig. 10(A). Two different Nb10 samples were investigated: one with average grain size of $\sim 1 \mu \mathrm{m}$ and another with $\sim 0.1 \mu \mathrm{m}$, with no apparent effect of the grain size on the bulk conductivity, thus only results of the specimen with the smallest grains are presented. The significant influence of the electronic conductivity of $\mathrm{Nb} 30$ will be described in a separate report, where hydrogen permeation due to a combination of electronic and proton conductivity is reported. ${ }^{30}$ The proton conductivity is not easily obtained from the electronic conductivity for these composites due to the dominating contribution from the electronic conductivity of $\mathrm{LaNb}_{3} \mathrm{O}_{9} .{ }^{31,32}$ The capacitances of the materials characterized by impedance spectroscopy are reported in Table II together with the average grain size, relative density, and calculated grain boundary width of the materials. The inverse phase boundary resistance of the corresponding materials is plotted in Fig. 10(B). The resistance from the phase boundaries increases with increasing $\mathrm{La}_{2} \mathrm{O}_{3}$-content and is also larger for Nb10 compared with LN. The phase boundary resistance dominates the total resistance of the materials in the temperature range $300-700^{\circ} \mathrm{C}$. The attempt to heterodope $\mathrm{LaNbO}_{4}$ with the two minority phases investigated here does therefore decrease the total conductivity of the materials. The total conductivity and the phase boundary resistivity showed only minor variation despite the relatively large variation in the phase composition and the phase content; hence, contributions from the various interfaces, as illustrated in Fig. 1(F)-(H), could not be separated.

The $p_{\mathrm{H} 2 \mathrm{O}}$ and $p_{\mathrm{O} 2}$ dependence of the conductivity was measured at $1000^{\circ} \mathrm{C}$. The dependence with water vapor pressure is shown in Fig. 11. Pure LN demonstrated a stronger $p_{\mathrm{H} 2 \mathrm{O}}$ dependence compared with both $\mathrm{Nb} 10$ and La10, similar to previously reported values for acceptor-doped $\mathrm{LaNbO}_{4}{ }^{2}$ The electrical conductivity as function of oxygen partial pressure for the materials $\mathrm{LN}$, La10, and $\mathrm{Nb10}$ is shown in Fig. 12. LN and La10 possess the same $p$-type behavior at high oxygen partial pressures. At lower $p_{\mathrm{O} 2}$, Nb10 proved to be more $n$-type conducting than the other materials, which can be attributed to electronic conductivity of the $\mathrm{LaNb}_{3} \mathrm{O}_{9}$-phase in the material.

\section{Discussion}

The five different materials investigated here sintered within a narrow densification temperature window as shown in Fig. 4(A), with a relative shift in temperature as expected from dilatometry (Fig. 3). The onset temperature of densification was lower for the excess $\mathrm{Nb}_{2} \mathrm{O}_{5}$ materials, while it increased with $\mathrm{La}_{2} \mathrm{O}_{3}$-excess relative to stoichiometric $\mathrm{LN}$. This reflects the melting temperatures of the minority oxides, which is higher for $\mathrm{La}_{3} \mathrm{NbO}_{7}$ than for $\mathrm{LaNb}_{3} \mathrm{O}_{9}{ }^{33}$ Solid-state sintering or cation mobility can roughly be expected to initiate at $2 / 3$ of the melting point ${ }^{34}$ and the eutectic temperature on the $\mathrm{La}_{2} \mathrm{O}_{3}$-rich side of $\mathrm{LN}$ is about $235^{\circ} \mathrm{C}$ higher than the eutectic temperature of $1354^{\circ} \mathrm{C}$ between $\mathrm{LaNb}_{3} \mathrm{O}_{9}$ and $\mathrm{LN} .^{33}$ Intuitively, one would expect that higher valence would lead to lower mobility, but the lower melting point increases the cation mobility as reported previously. ${ }^{8}$ SPS and HT-sintered LN reached close to full density at approximately the same temperature, with only half the applied pressure during HP, but with longer sintering time (Table I). At temperatures lower than $950^{\circ} \mathrm{C}$, the higher density of SPS samples compared with HP may be due to the higher applied pressure and not due to different mass transport mechanisms. The grain growth of pure LN followed the same trend with increasing temperature for the three different densification routes, but the grains in the dense SPS samples were larger than in the dense HP samples (Fig. 5). This may suggest the
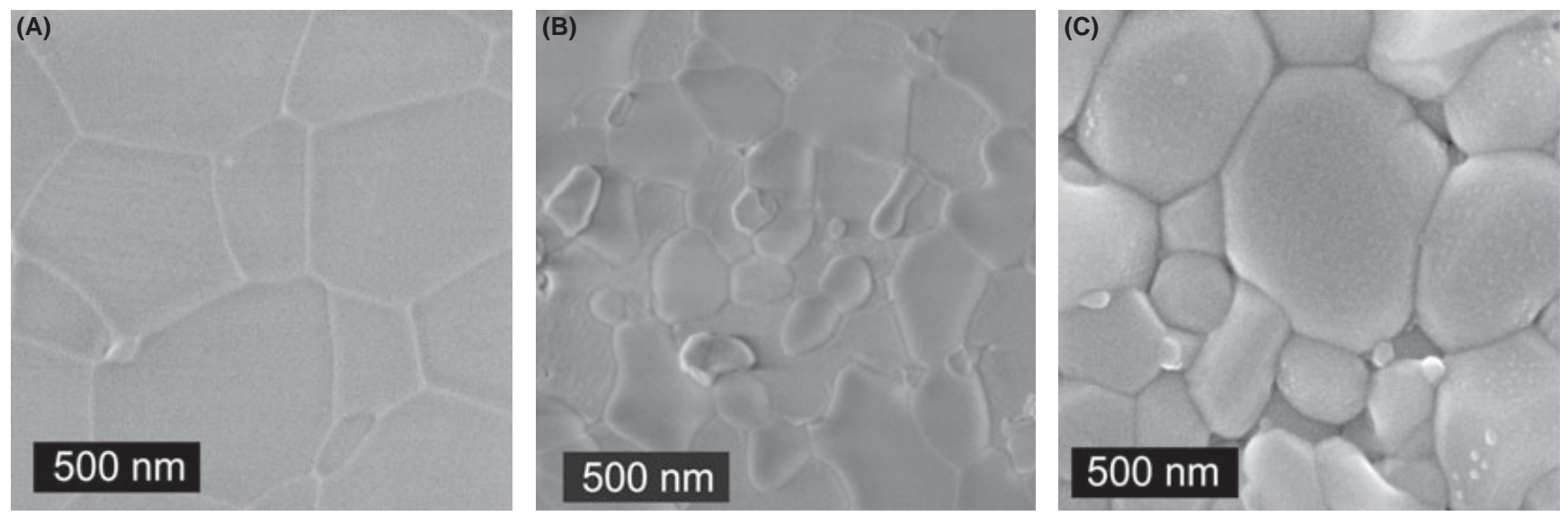

Fig. 8. Secondary electron images of (A) LN spark plasma sintered at $875^{\circ} \mathrm{C}$ for 1 min at $120 \mathrm{MPa}$, (B) $\mathrm{Nb} 30$ spark plasma sintered at $900^{\circ} \mathrm{C}$ for $2^{\circ} \mathrm{min}$ at $100 \mathrm{MPa}$, and (C) La30 spark plasma sintered at $1100^{\circ} \mathrm{C}$ for $1 \mathrm{~min}$ at $100 \mathrm{MPa}$. The tiny particles on the surface are carbon from the coating of the surface. 
presence of additional mechanisms like electromigration occurring during SPS due to the potential gradient across the sample, ${ }^{35}$ but this might also be due to uncertainty in the
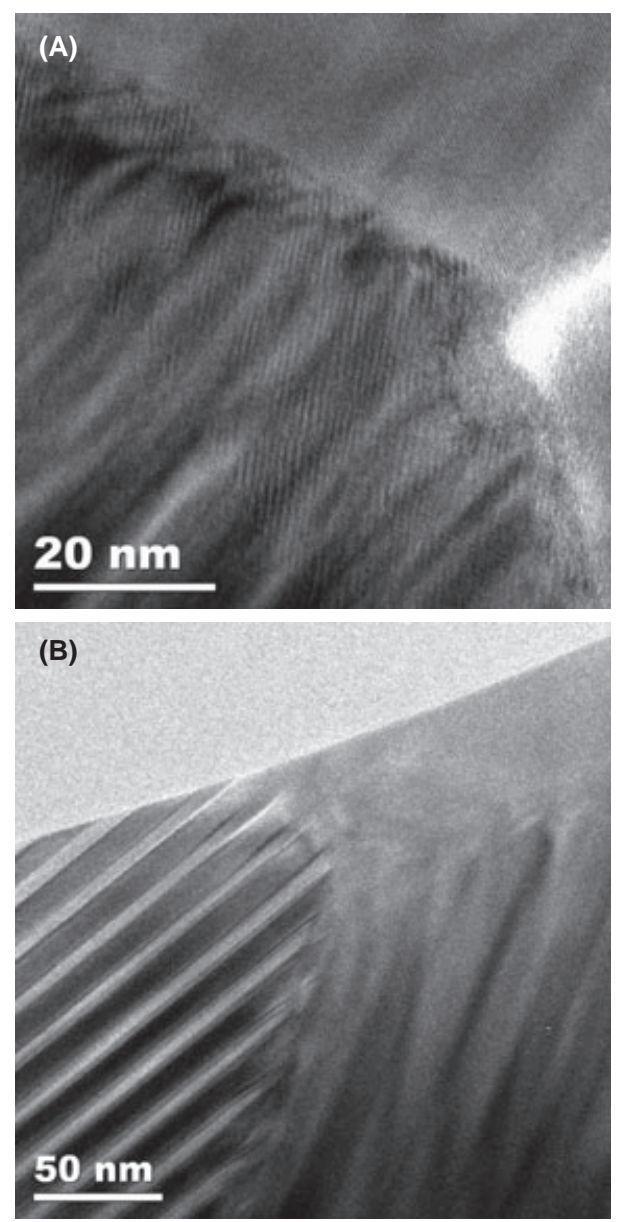

Fig. 9. HRTEM-image of Lal0 sample with no visible secondary phase between the grains (A). TEM-image of La10 sample showing the ferroelastic domains in the $\mathrm{LaNbO}_{4}$ grains (B). temperature measured during SPS or HP. Swelling may also occur at higher temperatures due to pore coarsening, lowering the relative density. ${ }^{34}$

The kinetics of grain growth will be affected strongly by the number of phases present in the material. This is clearly observed in Fig. 4, where extensive grain growth occurred in single-phase LN compared with its composite siblings. Densification competes against grain growth and coarsening, and it seems that the grains grew faster than the materials' ability to reach full density as seen in Fig. 5, where the grain growth becomes quite pronounced above $\sim 90 \%$ of theoretical density. This leads to severe difficulties achieving sub-100 nm grains in the dense materials. A wide particle size distribution of the starting powder will give grain coarsening, ${ }^{34}$ but the powders used here possess a narrow size distribution. ${ }^{24}$ The grain growth of the majority LN phase was strongly influenced by the pinning effect due to the minority phases. The $\mathrm{Nb}_{2} \mathrm{O}_{5}$-rich composites experienced more grain growth than the $\mathrm{La}_{2} \mathrm{O}_{3^{-}}$ rich composites, which reflects the higher cation mobility in the $\mathrm{Nb}_{2} \mathrm{O}_{5}$-excess materials. This behavior was expected as $\mathrm{La}_{3} \mathrm{NbO}_{7}$ has a higher melting point than $\mathrm{LaNbO}_{4}$, while $\mathrm{LaNb}_{3} \mathrm{O}_{9}$ has a lower melting point than $\mathrm{LaNbO}_{4}$.

The $30 \mathrm{vol} \%$ composites demonstrate a tendency toward smaller grains at the same density compared with the $10 \mathrm{vol} \%$ composites (Fig. 5). For the $\mathrm{La}_{2} \mathrm{O}_{3}$-rich composites, this can be explained by the larger volume fraction of $\mathrm{La}_{3} \mathrm{NbO}_{7}$ hindering $\mathrm{LaNbO}_{4}$ grains from growing due to a gradual percolation of the minority phase. At lower temperatures, the $\mathrm{LaNbO}_{4}$ grains coarsened as they were calcined, and when the minority phase starts to densify at a higher temperature, there is less space for these grains to grow. In the case of the $\mathrm{Nb}_{2} \mathrm{O}_{5}$-rich composites, the opposite occurred as $\mathrm{LaNb}_{3} \mathrm{O}_{9}$ starts to sinter first due to lower melting temperature, lowering the possibility for grain growth of $\mathrm{LaNbO}_{4}$. In the $10 \mathrm{vol} \%$ composites, the volume fractions of minority phase are too small to obtain percolation and give this effect. The grains of the minority phase pinned the mobility of the grain boundaries, which again led to reduced grain growth.

The crystallite size determined from diffraction reflects the ferroelastic domain size and not the true grain size, and the correlation between these two is shown in Fig. 6. There is clearly a size effect on the cell parameters (Fig. 7) as well as on the unit cell volume as shown in Fig. 13. With decreasing
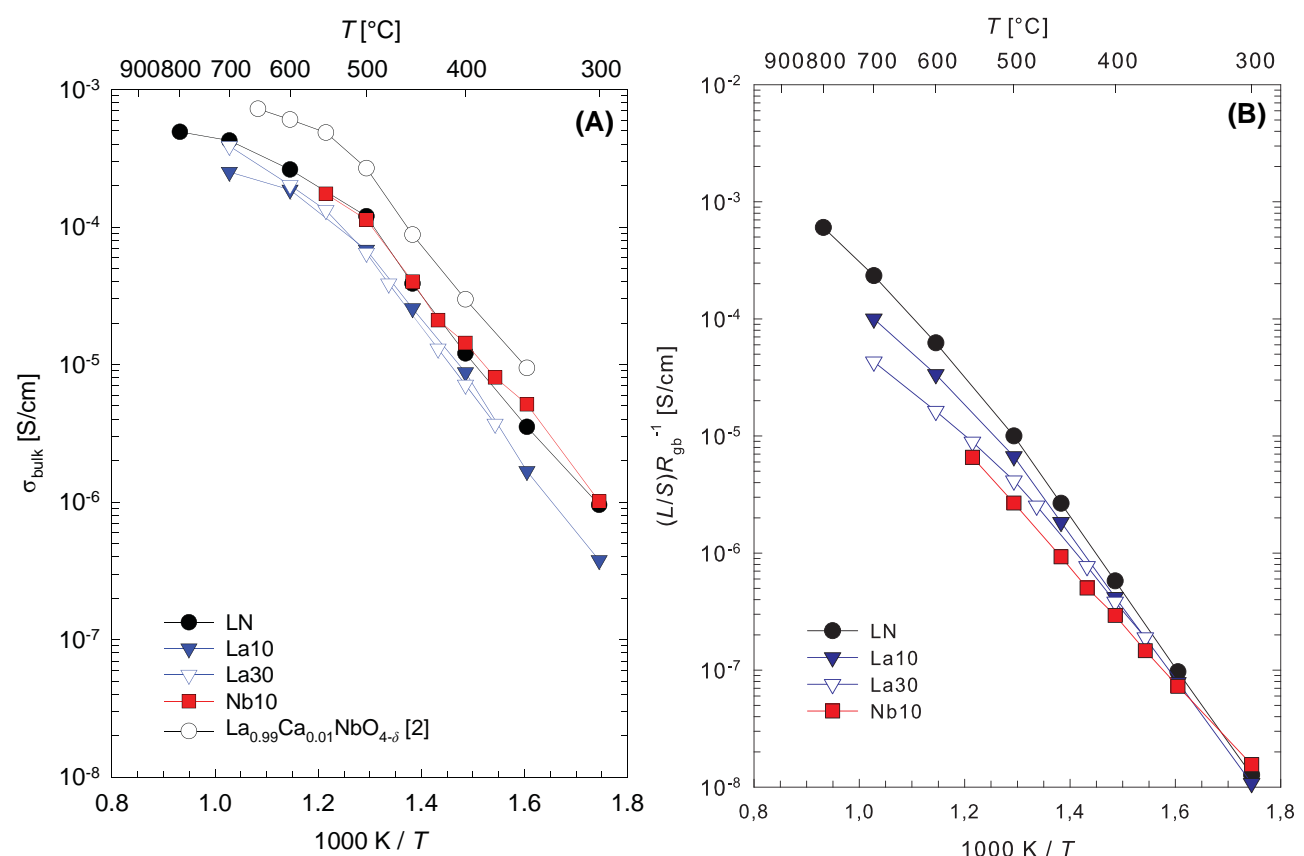

Fig. 10. Bulk conductivity (A) and inverse phase boundary resistance (B) plotted against inverse temperature for the materials LN, Nb10, La10, and La30 in wet, reducing atmosphere $\left(2.5 \% \mathrm{H}_{2} \mathrm{O}, 5 \% \mathrm{H}_{2} / \mathrm{N}_{2}\right) . S$ and $L$ are the electrode area and sample thickness, respectively. Bulk conductivity for $\mathrm{La}_{0.99} \mathrm{Ca}_{0.01} \mathrm{NbO}_{4-\delta}$ from Haugsrud and Norby ${ }^{2}$ is inserted in $\mathrm{A}$. 
Table II. Average Capacitances of Bulk, Phase Boundary, and Electrode, Together With Average Grain Size, Grain Boundary Thickness, and Relative Density of LN, La10, La30, and Nb10 Studied by Impedance Spectroscopy

\begin{tabular}{lcrcrc}
\hline Material & $\begin{array}{c}\mathrm{C}_{1} \\
{\left[10^{-12} \mathrm{~F} / \mathrm{cm}\right]}\end{array}$ & $\begin{array}{c}\mathrm{C}_{2} \\
{\left[10^{-11} \mathrm{~F} / \mathrm{cm}\right]}\end{array}$ & $\begin{array}{c}\mathrm{C}_{3} \\
{\left[10^{-9} \mathrm{~F} / \mathrm{cm}\right]}\end{array}$ & $\begin{array}{c}\text { Av. Grain } \\
\text { size [nm] }\end{array}$ & $\begin{array}{c}\text { Grain boundary } \\
\text { width [nm] }\end{array}$ \\
\hline LN & $5.3 \pm 0.8$ & $18.0 \pm 7.0$ & $110 \pm 50$ & $565 \pm 74$ & 17 \\
La10 & $4.7 \pm 0.2$ & $5.1 \pm 1.9$ & $7.0 \pm 8.4$ & $349 \pm 81$ & 32 \\
La30 & $4.5 \pm 0.6$ & $1.7 \pm 0.6$ & $5.2 \pm 0.3$ & $296 \pm 48$ & 78 \\
Nb10 & $4.0 \pm 0.6$ & $4.5 \pm 0.4$ & $2.0 \pm 0.2$ & $109 \pm 19$ & 92.6 \\
density [\%]
\end{tabular}

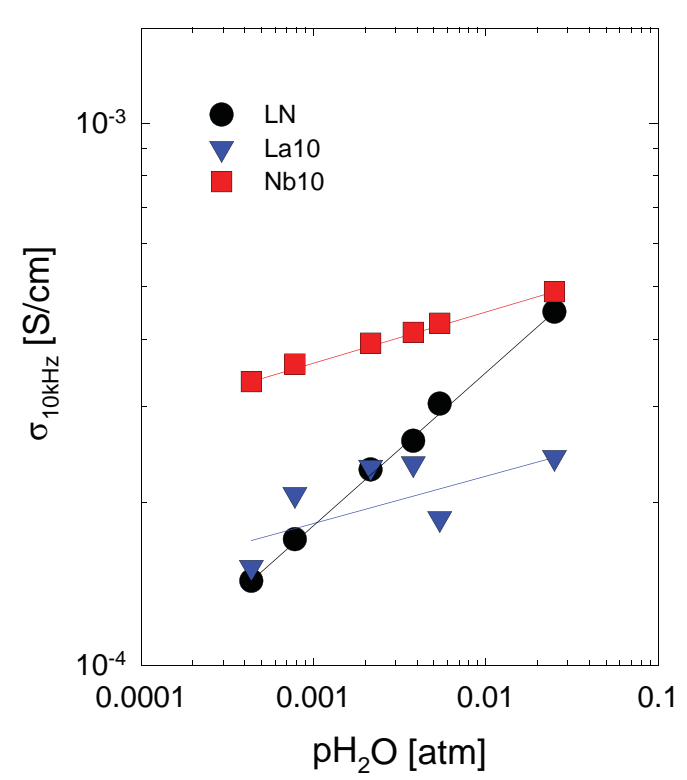

Fig. 11. $10 \mathrm{kHz}$ ac-conductivity of $\mathrm{LN}, \mathrm{Nb} 10$, and La10 versus water partial pressure under reducing conditions $\left(5 \% \mathrm{H}_{2} / \mathrm{Ar}\right)$ at $1000^{\circ} \mathrm{C}$.

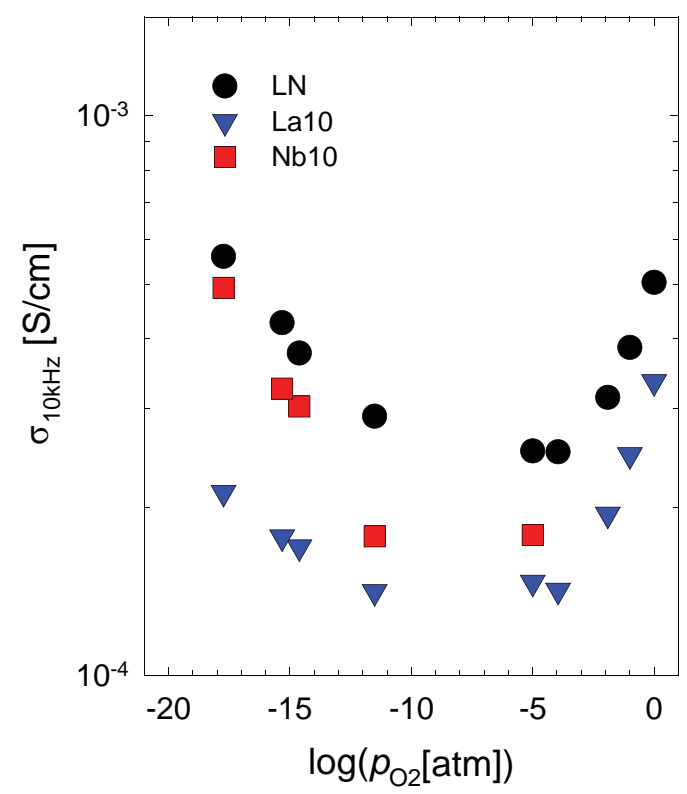

Fig. 12. Oxygen partial pressure dependency on $10 \mathrm{kHz}$ ac-conductivity under wet conditions $\left(2.5 \% \mathrm{H}_{2} \mathrm{O}\right)$ at $1000^{\circ} \mathrm{C}$.

crystallite size, the diffraction data point to an orthorhombic space group $\left(a \neq c\right.$ and $\left.\beta=90^{\circ}\right)$ before the crystallites eventually became, if extrapolated, tetragonal $\left(a=c\right.$ and $\left.\beta=90^{\circ}\right)$ at crystallite sizes significantly smaller than obtained in this work. ${ }^{3}$ Increasing symmetry by reducing the crystallite size

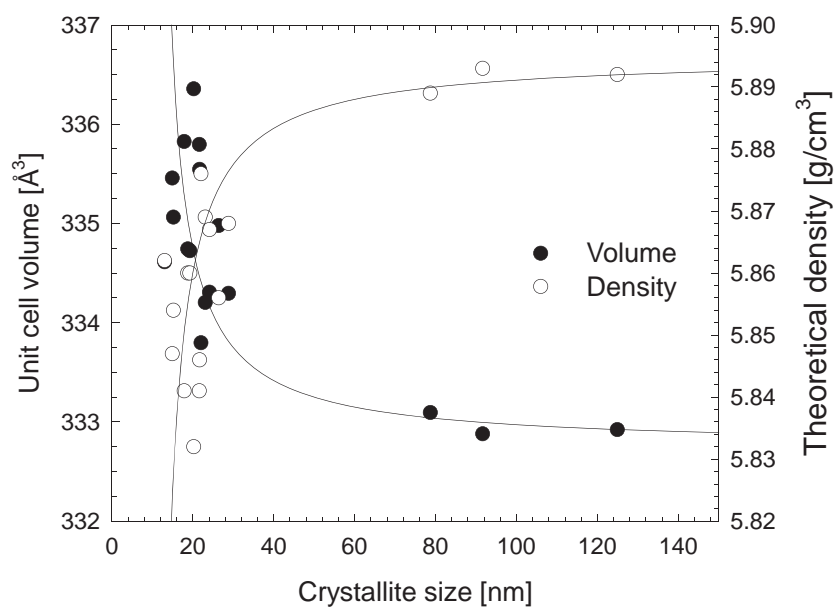

Fig. 13. Unit cell volume and theoretical density as function of crystallite size. Lines are added as guides to the eye.

has been observed for other materials, such as $\mathrm{Al}_{2} \mathrm{O}_{3}$ and $\mathrm{ZrO}_{2}$, and can be related to the higher surface energy of the stable low symmetry polymorphs. ${ }^{36,37}$

The diffraction pattern of the SPS samples was quite similar to the diffraction pattern of the calcined powders. The broad diffraction lines of the calcined powders are expected due to particle size broadening and possible inhomogeneities not removed during calcination at $650^{\circ} \mathrm{C}$. The reduced crystallinity of the SPS materials was more surprising and not straight forward to explain. Broadening due to the grain size may contribute, although the grain size is not small enough, to give such an effect. We therefore suggest that additional broadening is caused by the small ferroeleastic domain size of the SPS materials. The SPS samples were quenched through the ferroelastic transition (for example cooling from $550^{\circ} \mathrm{C}$ to $450^{\circ} \mathrm{C}$ occurred in less than one minute). This could induce domain nucleation at a larger extent than for slowly cooled samples domain growth may occur. When the disks were crushed into powder, the crystallite size increased significantly, and the intensity of the reflections from the planes non-parallel to the [010] zone axis became stronger (Fig. 14). The remnant strain is lost during grinding as the strain from the neighboring grains is removed, which suggests that domains with preferential orientation perpendicular to the pressing direction are formed during cooling in a mechanical field.

The tolerance for cation nonstoichiometry in $\mathrm{LaNbO}_{4}$ materials is low, ${ }^{8}$ and the two minority phases studied here have been reported to possess a higher solubility of $\mathrm{CaO}$ or $\mathrm{SrO}$ than $\mathrm{LaNbO}_{4} \cdot{ }^{38-40}$ It is therefore interesting to note the accumulation of calcium in $\mathrm{La}_{3} \mathrm{NbO}_{7}$ and $\mathrm{LaNb}_{3} \mathrm{O}_{9}$. Accumulation of calcium in the minority phases could have an effect on the proton conductivity of the materials, as undoped $\mathrm{LaNbO}_{4}$ is reported to have a proton conductivity at least one order of magnitude lower than $\mathrm{Ca}$-doped $\mathrm{LaNbO}_{4}{ }^{7}$ However, there is no evidence of lower bulk conductivity in the composites than in LN (Fig. 10). The small variation in bulk conductivity can be allocated to the lower and higher 


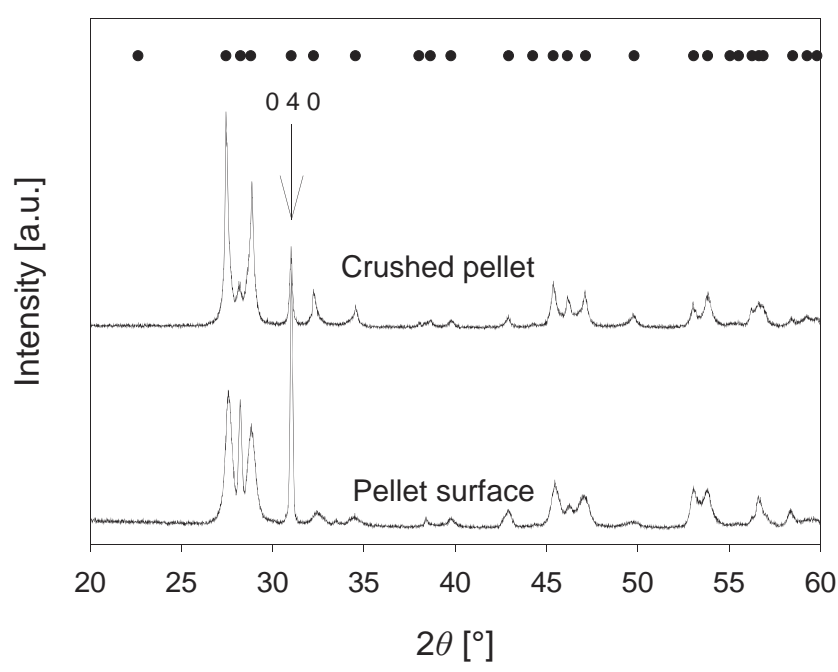

Fig. 14. Comparison of XRD of a polished LN pellet surface prepared by SPS and crushed powder of the same pellet. $\mathrm{LaNbO}_{4}$ pattern from Tsunekawa et al. is included. ${ }^{4}$

conductivity of $\mathrm{La}_{3} \mathrm{NbO}_{7}$ and $\mathrm{La}_{3} \mathrm{NbO}_{9}$ (electronic), relative to LN. As calcium was only detected in the minority phases, one can assume that the maximum doping level in $\mathrm{LN}$ is lower than $0.5 \mathrm{~mol} \%$, which is in agreement with recent suggestions $^{8}$. In the case of $\mathrm{LN}$, excess calcium exceeding the solubility limit will cause the formation of traces of secondary phases. The increased effective phase boundary resistance in the composite may be caused by the increased number of grain boundaries, as a consequence of decreasing grain size, or by the introduction of new type of phase boundaries, which may increase the space charge potential, the opposite effect of which was intended. The large phase boundary thickness in Table II indicates low bulk concentration of charge carriers and large space charge potentials.

To observe any effect of hetero-doping on the electrical or proton conductivity, it requires that the grain size of the materials is small and that the minority phase percolates and gives only heterophase grain boundaries as illustrated in Fig. 1(A). Formation of such percolating heterophase boundaries is depressed with large dihedral angles and the situation is then better described by Fig. 1(B). Furthermore, the volume fraction needed to obtain a percolating minority phase decreases with decreasing grain size of the minority phase. Because of the fast grain growth of the materials studied here, small grains of the minority phase were not located on the grain boundaries of the majority phase in either of the materials, thus not creating the percolating "phase boundary zone" depicted in Fig. 1(E), suggesting a large dihedral angle between the phases. Therefore, the situation was rather a mix of boundaries, as illustrated in Fig. $1(\mathrm{~F})-(\mathrm{H})$, and the minority phases in La10 and Nb10 acted as isolated islands and did not contribute significantly to the overall conductivity. However, in the case of the $30 \mathrm{vol} \%$ materials, percolation of the minority phase occurred. In $\mathrm{Nb} 30$, percolation of $\mathrm{LaNb}_{3} \mathrm{O}_{9}$ was obvious, as this phase is known to be $n$-type semiconducting, ${ }^{31,32}$ causing the large increase in electronic conductivity of $\mathrm{Nb30}$. In the case of La30, the conductivity was lowered due to bulk $\mathrm{La}_{3} \mathrm{NbO}_{7}$ percolation, as the conductivity of this phase is lower than for the Ca-doped $\mathrm{LaNbO}_{4}$. Finally, recent attempts of homo-doping of $\mathrm{LaNbO}_{4}$ have not been particularly successful with respect to increasing the proton conductivity. ${ }^{9,10,41,42}$ It seems therefore difficult to increase the proton conductivity of $\mathrm{LaNbO}_{4}$ above the level reported initially. ${ }^{1,2}$

\section{Conclusion}

The present work has demonstrated that dense composites of $\mathrm{LaNbO}_{4}$ and $\mathrm{LaNb}_{3} \mathrm{O}_{9}$ or $\mathrm{La}_{3} \mathrm{NbO}_{7}$ can be prepared by HP,
SPS, and CS. The sintering temperature of $\mathrm{LaNbO}_{4}$ was reduced significantly by SPS or HP compared with conventional sintering. Coarsening occurred prior to densification for all the hetero-doped materials, and preparation of dense materials with a grain size below $100 \mathrm{~nm}$ could not be achieved. The unit cell parameters for monoclinic $\mathrm{LaNbO}_{4}$ were dependent on the crystallite size and approached values for tetragonal $\mathrm{LaNbO}_{4}$ with reducing grain size. The minority phases in the composites were mainly present at triple points and not along the grain boundaries due to a large dihedral angle between the phases. $\mathrm{CaO}$ was shown to accumulate in the minority phases $\mathrm{La}_{3} \mathrm{NbO}_{7}$ and $\mathrm{LaNb}_{3} \mathrm{O}_{9}$, respectively, due to a higher CaO-solubility than $\mathrm{LaNbO}_{4}$. The approach to hetero-dope $\mathrm{LaNbO}_{4}$ by $\mathrm{La}_{3} \mathrm{NbO}_{7}$ and $\mathrm{LaNb}_{3} \mathrm{O}_{9}$ did not possess any substantial effect on the overall conductivity of the $\mathrm{LaNbO}_{4}$ materials, and single-phase $\mathrm{LaNbO}_{4}$ materials are therefore preferential as electrolyte materials.

\section{Acknowledgment}

This work has been financially supported by the Research Council of Norway (NFR) through grant no. 182090 (nanoPCFC).

\section{References}

${ }^{1}$ R. Haugsrud, and T. Norby, "Proton Conduction in Rare-Earth OrthoNiobates and Ortho-antalates," Nat. Mater., 5 [3] 193-6 (2006a).

${ }^{2}$ R. Haugsrud, and T. Norby, "High-Temperature Proton Conductivity in Acceptor-Doped $\mathrm{LaNbO}_{4}$," Solid State Ionics, 177 [13-14] 1129-35 (2006b).

${ }^{3}$ W. I. F. David, "The High-Temperature Paraelastic Structure of $\mathrm{LaNbO}_{4}$," Mater. Res. Bull., 18 [6] 749-56 (1983).

${ }^{4} \mathrm{~S}$. Tsunekawa, T. Kamiyama, K. Sasaki, H. Asano, and T. Fukuda, "Precise Structure Analysis by Neutron Diffraction for $\mathrm{RNbO}_{4}$ and Distortion of $\mathrm{NbO}_{4}$ Tetrahedra," Acta Crystallogr. A, 49 [4] 595-600 (1993).

${ }^{5}$ K. D. Kreuer, "Aspects of the Formation and Mobility of Protonic Charge Carriers and the Stability of Perovskite-Type Oxides," Solid State Ionics, 125 [1-4] 285-302 (1999).

${ }^{6}$ H. Fjeld, D. M. Kepaptsoglou, R. Haugsrud, and T. Norby, "Charge Carriers in Grain Boundaries of $0.5 \%$ Sr-Doped $\mathrm{LaNbO}_{4}$," Solid State Ionics, 181 [3-4] 104-9 (2010).

${ }^{7}$ T. Mokkelbost, I. Kaus, R. Haugsrud, T. Norby, T. Grande, and M.-A Einarsrud, "High-Temperature Proton-Conducting Lanthanum Ortho-Niobate-Based Materials. Part II: Sintering Properties and Solubility of Alkaline Earth Oxides," J. Am. Ceram. Soc., 91 [3] 879-86 (2008).

${ }^{8}$ G. E. Syvertsen, A. Magrasó, R. Haugsrud, M. A. Einarsrud, and T. Grande, "The Effect of Cation non-Stoichiometry in $\mathrm{LaNbO}_{4}$ Materials," Int. J. Hydrogen Energy, http://dx.doi.org/10.1016/j.ijhydene.2011. 10.113.

${ }^{9}$ M. Ivanova, S. Ricote, W. A. Meulenberg, R. Haugsrud, and M. Ziegner, "Effects of A- and B-Site (co-)Acceptor Doping on the Structure and Proton Conductivity of $\mathrm{LaNbO}_{4}$," Solid State Ionics, http://dx.doi.org/10.1016/j. ssi.2011.06.012.

${ }^{10} \mathrm{M}$. Huse, T. Norby, and R. Haugsrud, "Effects of A and B Site Doping on Hydration and Proton Mobility of $\mathrm{LaNbO}_{4}$, , Int. J. Hydrogen Energy, http://dx. doi.org/10.1016/j.ijhydene.2011.10.020.

${ }^{11}$ J. Maier, "Composite Electrolytes," Mater. Chem. Phys., 17 [5] 485-98 (1987).

${ }^{12}$ J. Maier, "Nanoionics: Ion Transport and Electrochemical Storage in Confined Systems," Nat. Mater., 4 [11] 805-15 (2005).

${ }^{13}$ J. Maier, Physical Chemistry of Ionic Materials, 1st edition. John Wiley \& Sons, Chichester, (2004).

${ }^{14} \mathrm{~S}$. Stølen, and T. Grande, Chemical Thermodynamics of Materials. John WIley \& Sons Ltd, Chichester, (2004).

${ }^{15}$ J. Maier, "Ionic Conduction in Space Charge Regions," Prog. Solid State Ch., 23 171-263 (1995)

${ }^{16}$ M. Aoki, Y.-M. Chiang, I. Kosacki, L. J.-R. Lee, H. Tuller, and Y. Liu, "Solute Segregation and Grain-Boundary Impedance in High-Purity Stabilized Zirconia," J. Am. Ceram. Soc., 79 [5] 1169-80 (1996).

${ }^{17}$ C. C. Liang, "Conduction Characteristics of the Lithium IodideAluminum Oxide Solid Electrolytes," J. Electrochem. Soc., 120 [10] 1289-92 (1973).

${ }^{18}$ J. Maier, "Space Charge Regions in Solid two-Phase Systems and Their Conduction Contribution. I. Conductance Enhancement in the System Ionic Conductor.'inert' Phase and Application on $\mathrm{AgCl} \cdot \mathrm{Al}_{2} \mathrm{O}_{3}$ and $\mathrm{AgCl} \cdot \mathrm{SiO}_{2}, " J$. Phys. Chem. Solids, 46 309-20 (1985).

${ }^{19}$ N. Sata, K. Eberman, K. Eberl, and J. Maier, "Mesoscopic Fast ion Conduction in Nanometre-Scale Planar Heterostructures," Nature, 408 [6815] 9469 (2000).

${ }^{20}$ N. J. Kidner, Z. J. Homrighaus, B. J. Ingram, T. O. Mason, and E. J. Garboczi, "Impedance/Dielectric Spectroscopy of Electroceramics-Part 1: Evaluation of Composite Models for Polycrystalline Ceramics," J. Electroceramics, 14 [3] 283-91 (2005). 
${ }^{21}$ M. Omori, "Sintering, Consolidation, Reaction and Crystal Growth by the Spark Plasma System (SPS)," Materials Science and Engineering A, 287 [2] 183-8 (2000).

${ }^{22}$ L. Gao, Z. Shen, H. Miyamoto, and M. Nygren, "Superfast Densification of Oxide/Oxide Ceramic Composites," J. Am. Ceram. Soc., 82 [4] 1061-3 (1999).

${ }^{23}$ J. Maier, "Acid-Base Centers and Acid-Base Scales in Ionic Solids," Chem. Eur. J., 7 [22] 4762-70 (2001).

${ }^{24}$ T. Mokkelbost, Ø. Andersen, R. A. Strøm, K. Wiik, T. Grande, and M.A. Einarsrud, "High-Temperature Proton-Conducting LaNbO $\mathrm{L}_{4}$-Based Materials: Powder Synthesis by Spray Pyrolysis," J. Am. Ceram. Soc., 90 [11] 3395 400 (2007).

${ }^{25}$ A. Kahn-Harari, L. Mazerolles, D. Michel, and F. Robert, "Structural Description of $\mathrm{La}_{3} \mathrm{NbO}_{7}$, , J. Solid State Chem., 116 [1] 103-6 (1995).

${ }^{26}$ B. J. Kennedy, C. J. Howard, Y. Kubota, and K. Kato, "Phase Transition Behaviour in the A-Site Deficient Perovskite Oxide $\mathrm{La}_{1 / 3} \mathrm{NbO}_{3}$, , J. Solid State Chem., 177 [12] 4552-6 (2004).

${ }^{27}$ S. M. Haile, D. L. West, and J. Campbell, "The Role of Microstructure and Processing on the Proton Conducting Properties of Gadolinium-Doped Barium Cerate," J. Mater. Res., 13 [6] 1576-95 (1998).

${ }^{28}$ O. Prytz, and J. Tafto, "Accurate Determination of Domain Boundary Orientation in $\mathrm{LaNbO}_{4}$, , Acta Mater., 53 [2] 297-302 (2005).

${ }^{29}$ S. Tsunekawa, A. Kasuya, and Y. Nishina, "Shape and Size Controls of Micro-Domains in $\mathrm{LaNbO}_{4}$ Crystals," Mat. Sci. Eng. A-Struct., 217-218 215-7 (1996).

${ }^{30}$ W. Xing, G. E. Syvertsen, T. Grande, Z. Li, and R. Haugsrud, "Hydrogen Permeation and Transport Properties in Ca-doped $\mathrm{LaNbO}_{4}$ and $\mathrm{LaNb}_{3} \mathrm{O}_{9}$ Composites," to be submitted.

${ }^{31}$ A. M. George, and A. N. Virkar, "Mixed Iono-Electronic Conduction in $\beta-\mathrm{LaNb}_{3} \mathrm{O}_{9}, " J$. Phys. Chem. Solids, 49 [7] 743-51 (1988).
${ }^{32}$ E. Orgaz, and A. Huanosta, "Electric Transport Properties of the $\beta$ $\mathrm{LnNb}_{3} \mathrm{O}_{9}$ Phases $(\mathrm{Ln}=\mathrm{La}, \mathrm{Ce}, \mathrm{Pr}$, and Nd), J. Solid State Chem., 97 [1] 65 73 (1992).

${ }^{33}$ E. P. Savchenko, N. A. Godina, and E. K. Keler, Proc. All-Union Conf. 2nd edition, Leningrad, USSR: Consultants Bureau, New York, 1969.

${ }^{34}$ R. M. German, Sintering Theory and Practice. John Wiley \& Sons, New York, 1996.

${ }^{35}$ E. Olevsky, and L. Froyen, "Constitutive Modeling of Spark-Plasma Sintering of Conductive Materials," Scr. Mater., 55 [12] 1175-8 (2006).

${ }^{36}$ J. M. McHale, A. Auroux, A. Perrotta, and A. Navrotsky, "Surface Energies and Thermodynamic Phase Stability in Nanocrystalline Aluminas," Science, 277 788-91 (1997).

${ }^{37}$ R. C. Garvie, "Stabilization of the Tetragonal Structure in Zirconia Microcrystals," J. Phys. Chem., 82 [2] 218-24 (1978).

${ }^{38}$ A. M. Frolov, and A. A. Evdokimov, "The Isothermal Section of CaO$\mathrm{La}_{2} \mathrm{O}_{3}-\mathrm{Nb}_{2} \mathrm{O}_{5}$ System," Russ. J. Inorg. Chem (Engl. Transl.), 32 1771-3 (1987).

${ }^{39}$ A. Magrasó, and M.-L. Fontaine, "Investigation of Compatible Anode Systems for $\mathrm{LaNbO}_{4}$-Based Electrolyte in Novel Proton Conducting Solid Oxide Fuel Cells," J. Power Sources, 196 [23] 10183-90 (2011).

${ }^{40}$ T. Shimura, Y. Tokiwa, and H. Iwahara, "Protonic Conduction in Lanthanum Strontium Aluminate and Lanthanum Niobate-Based Oxides at Elevated Temperatures," Solid State Ionics, 154-155 653-8 (2002).

${ }^{41}$ A. D. Brandão, I. Antunes, J. R. Frade, J. Torre, V. V. Kharton, and D. P. Flagg, "Enhanced Low-Temperature Proton Conduction in $\mathrm{Sr}_{0.02} \mathrm{La}_{0.98} \mathrm{NbO}_{4-}$ by Scheelite Phase Retention," Chem. Mater., 22 [667] 3-6683 (2010).

${ }_{42}$ A. D. Brandão, J. Gracio, G. C. Mather, V. V. Kharton, and D. P. Fagg, "B-Site Substitutions in $\mathrm{LaNb}_{1-\mathrm{x}} \mathrm{M}_{\mathrm{x}} \mathrm{O}_{4-\delta}$ Materials in the Search for Potential Proton Conductors $(\mathrm{M}=\mathrm{Ga}, \mathrm{Ge}, \mathrm{Si}, \mathrm{B}, \mathrm{Ti}, \mathrm{Zr}, \mathrm{P}, \mathrm{Al})$," J. Solid State Chem., $184863-70$ (2011) 